\title{
Chimbutane, Feliciano 2011. Rethinking bilingual education in postcolonial contexts. N. H. Hornberger and C. Baker ed Bristol, Buffalo, Toronto: multilingual matters. 183p.
}

Michel Lafon ${ }^{1,2,3}$

Correspondence:

michel lafon@up.ac.za

${ }^{1}$ Research Fellow, Center for Research on the Politics of Language, University of Pretoria, Pretoria, South Africa

${ }^{2}$ IFAS, Johannesburg, South Africa Full list of author information is available at the end of the article
It is no new finding (inter alia Tsui \& Tollefson 2004) that, in post-colonial countries, political considerations weigh decisively on the choice of Medium of Instruction (MoI) in school. For instance, in an attempt to break away from the colonial language and affirm their new political belonging, Northern African countries, once they attained independence, promoted Arabic. The move was eased by the example of Middle East countries and the resources they could offer, human and otherwise, even if it overlooked local linguistic realities - in particular Berber and local varieties of Arabic if not French - and jeopardized in the process education outcomes (see Mohamed (2007) for a detailed study of Algeria). However, with the possible exception of Tanzania and erstwhile Madagascar, most African countries south of the Sahara with no significant literate tradition in a language they could claim their own have refrained from such ambitious political statement. Rather, they have maintained the former colonial language throughout a generally expanding formal education system. When they feature, local languages are usually restricted to the early years (Alidou 2004) and their use remains highly controversial among many stakeholders (Qorro 2009).

In his case study of Mozambique which draws its argument from fieldwork in two sites of the southern Gaza province, Chimbutane demonstrates the intrinsic link between attitudes towards language choice in education proper and in society at large. Since 2003 an experiment in bilingual education, offered in a handful of rural schools, has proved so popular regardless of the many challenges it faced and continues to face that communities outside its planned scope have requested to be included. Thus the experiment has embraced 16 or 17 languages over the 7 initially considered and circa twice more classrooms and pupils (Lafon 2008, 2012 and 2013). This undeterred popularity has led the political leadership to change drastically its ideological stance. It is this dialectic that the book highlights, illustrating, given local circumstances, the 'emancipatory force' of the experiment (p167) (see also Chimbutane and Benson 2012). Whereas African languages, hardly recognized in the present Constitution (Governo de Moçambique 2004) had little space in public discourse, they are now part of a revamped concept of Mozambicanhood (p161) which appears as a mix where modernity blends with what Stroud aptly calls a "retraditionalisation" of society (2007:42, quoted p126). Emphasis is placed on retrieving and revitalising cultural roots, at times

(c) 2013 Lafon; licensee Springer. This is an Open Access article distributed under the terms of the Creative Commons Attribution License (http://creativecommons.org/licenses/by/2.0), which permits unrestricted use, distribution, and reproduction in any medium, provided the original work is properly cited. 
bordering on folkorisation as evidenced by the prominence given to dance and artefacts over language in the 2006-2010/11 Education plan (Governo de Moçambique 2006). And this new framework may reach far beyond education. A reflection on language policy was launched in 2008 by the Ministry of Culture and the shift in thinking was echoed in the Carta de Maputo emanating from the 2011 PALOP (Países Africanos de Lingua Oficial Portuguesa) meeting (Esteve Filimão, interviews, July 2010, October 2011; http://www.iilp.org.cv/; Lafon 2013). Whether the programme itself was cause or consequence of this change is of course hard to decide but I would contend that its launch was, probably unwittingly, the determining factor behind it.

Chimbutane's book is thus an invitation to reflect on issues pertaining to education in a very specific postcolonial setting. On the whole Chimbutane has succeeded in turning an academic degree - the book is based on a PhD elaborated at Birmingham in Great-Britain - into a readable and most useful volume. I will not deal here though with the main topic of the book. My contribution is meant as complementary rather than critical. I am concerned here with the historical background. I will present in some details aspects which, I contend, have been omitted, forgotten or underplayed in Chimbutane's otherwise thoughtfully managed study. This is not intended merely for the sake of setting historical records right but because, on the one hand, past policies of cultural denial are crucial to understand the dynamics of today's situation, and on the other, literary developments during the early assimilation period may offer cues to the much needed promotion of African languages, which is one of today's most rehearsed but less heeded leitmotivs.

\section{Frelimo's protracted denial}

One of the central points of Chimbutane's thesis is to highlight the positive impact that bilingual education in Mozambique, limited though its scope remains, has had on the speakers' own perception of the value of their language and culture (p 13 \& 15 \& 106), triggering a dramatic turn about of the dominant ideological discourse.

It is undeniable that part of the programme's popularity in rural areas stems from the novelty that it represented, after a protracted history of negation of African languages and values and might be taken as an illustration of the tendency to adhere to policies adverse to what was propounded during the colonial or pre-independence period, demonstrated $\grave{a}$ contrario by the example of South Africa (Lafon 2011). However Chimbutane passes very briefly (p3 \& seq.) over the Frelimo pre-1990 policy of modernism which attempted to relegate African languages to (at best) families (for instance Matusse 1994:545), conversely emphasizing the anecdotal use of African languages by President Samora Machel himself (p44, 160). Still this legacy, which invites itself inadvertently in a later passage (p124), is crucial to gain an understanding of attitudes which remain dominant, namely its popularity with rural communities and the reluctance of the administration to fully embrace the programme, which, if this were a clue to Chimbutane's discretion, would only prove my point further.

In Mozambique, not only were local languages systematically denigrated from the 1930s during colonial rule to the extent of being called 'dog's languages' according to a testimony (p110), but, as in few other places, they were further marginalized for a good 20 years after Independence, when they were referred to, as they still are, as 'dialects', thus denying them the status of a language. 
This came as a consequence of the Portuguese 'assimilation' policy, by means of which a small minority of Black and mulattoes (mixed-blood people, mestiços) were elevated almost to the level of the Portuguese settlers in terms of rights and privileges, including access to education, provided they adhered to Portuguese Christian values and attitudes (Mondlane 1979). The administrative unification of the whole indigenous population in 1961 with the rescission of forced labour and other vexing measures resulted, in urban areas, in further spreading assimilation as a desired model. At Independence in 1974 Frelimo adopted a Marxist discourse that espoused many ideological tenets of 'assimilation' for the sake of national unity and 'progress'. 'The project of national unity' (p99) echoed the $19^{\text {th }}$ century 'classical ideal of a centralised nation state' (Kamwangamalu 2008:174) in its Stalinist embodiment, which required one unique language for a nation to exist (Rocha 2006:19). If such concern in a country with no common history except that of suffering under the same colonial master (Mondlane 1979:96) is self-explanatory, especially as, due to the geo-political environment, it combined with a fear of being overpowered by English (Rothwell 2001), the obsession with the pursuance of 'progress' is not. Progress implied, for the Frelimo leadership, bringing forth a 'new man' (Mugomba 1981). For this to happen, it was deemed essential to relinquish the very same African practices deemed 'pagan', 'barbarian' or 'backwards' in the previous age and replace them by so-called 'modern' (viz., European-centred) ones, moreover uniform across the country. Language-wise, this meant the abandonment of the local languages seen as divisive in favour of the proclaimed national one, Portuguese, that extensive education programmes were disseminating. Local languages were prohibited in official places (Firmino 2005: 142). This strategy however was selfdefeating: how could the new revolutionary schools attain "a rich interaction with surrounding peasant communal villages" (Mugomba 1981: 216), a condition for their sustainability, without interacting with them in their own language and acknowledging their values? Since Geffray's 1990 pioneer study, this scenario has been widely exposed. Such disdain for time-tested engrained practices already encroached upon by colonial rule nurtured support for Renamo, an armed opposition movement triggered by the neighbouring racist states of Rhodesia and South Africa. I argue elsewhere (Lafon 2008 \& 2013) that one underlying reason for Frelimo's attitude culture-wise lies in the appropriation of the assimilation ideology by cadres most of whom emanated from this very minute strata. With very few exceptions, only former assimilados and mulattoes had had access to secondary schooling, and those who had not were fascinated by its trappings and had longed for the status.

It took the promulgation of a constitution allowing for multiparty democracy in 1994 in the wake of the peace agreement to give clearance to adult education programmes relying on local languages; and another ten years to see them considered, with extreme caution, in formal education.

\section{Early literacy developments in Mozambique - 'assimilação uniformizadora'}

One step deeper into the past, Chimbutane also underplays a unique episode in Mozambican history which may be of significance to-day. Even though he pays tribute to the important role played by Protestant churches in the instrumentalization and maintenance of African languages through biblical translation and other edifying texts, 
Chimbutane places the beginning of education for Africans in the 1930s, that is, when the state-supported Catholic Church was allowed to exercise a near monopoly over it (p46). Still, in the South, by the 1880s the Protestant Missions had already incepted a bilingual education of sorts, which was rapidly to bear fruits. This episode has been extensively described by Cruz e Silva (2001) and Harries (especially 2007). By 1896 there were already 900 'educated' Africans (Rocha 2006:99) most, it can safely be assumed, literate in their own language(s). The figure may seem small but in the conditions prevailing at the time this was not negligible. The Swiss Mission had started to print biblical translations in local languages (Cruz e Silva 2001:50), a feat which implied local agency. For example, from 1890 father Robert Ndevu Mashaba published religious works in Ronga and by 1908 the Bible was translated in Tswa. Moreover, Chimbutane sets the inception of the assimilation policy when it was officially promulgated in 1917 (p34). But, prior to the date, colonial policy had held promises of racial integration through 'assimilação uniformizadora' ('uniformising assimilation') (Rocha 2006:124). 'Educated' blacks and mulattoes, referred to as Black or African Portugueses or 'filhos da terra' (children of the soil), set apart from the mass of 'indigenes', enjoyed theoretically the same privileges as white Portugueses and some even occupied relatively high offices (Rocha 2006:40, 71). This subsided gradually after the influential Antonio Enes' 1893 report on the administration of the colony (Penvenne 1989:266), especially when the Republican administration in charge from 1910 tried to lure new settlers from the home country whose main qualification lay in their skin colour. Regulations were passed to establish job privileges for white Portugueses by containing 'assimilated' nonwhites, leading to the 1917 assimilado status which compelled them to carry a document and was largely perceived as a drawback. After the 1917 coup in Portugal which paved the way for Salazar's Estado Novo, eventually established in 1933, educational endeavours of Protestant missions, suspect of instilling dangerous ideas into native minds, were curtailed, their use of African languages being a ready excuse to target them.

Still, prior to this closure, from the early 1900s, emerged, among the 'filhos da terra', a political movement christened 'nativismo', known mostly through O Gremio Africano de Lourenço Marquès (The African Guild of LM, the name of the Portuguese settlement in the Maputo area). It was created and guided by the Albasini brothers, themselves mulattoes and widely seen as the founding fathers of Mozambican nationalism. If Portuguese took uncontested precedence in their practices and discourse - they pledged loyalty to Portugal (and hence to the language) even though they were harsh critics of some of its policies - they commonly and unashamedly used African languages in their bulletins. O Africano, The African, O Gremio's mouth-piece, founded in 1908, and its sequel O Brado Africano from 1918, were bi-, if not multi- lingual, as $O$ Africano's subtitle in Ronga illustrates (facsimile in Rocha 2006:115). The 1917 status which the Gremio vehemently and constantly opposed was published in Ronga (Rocha 2006:148, 151, 197). Granted, the Gremio's position on language was somewhat ambiguous. In an acceptance of the assimilation rationale, they demanded education and the teaching of Portuguese for all Africans as a step towards their improvement and equality with Whites, and looked down on African language literacy, criticising the Protestant missions' orientation in that regard (Cruz e Silva 2001; Rocha 2006). In the 1920s a splinter group published for some time Dambu dja Africana, The African Sun, purely in Ronga. As the split seems to have emerged from a cleavage between 
mulattoes and Black Africans, the language choice was probably a political statement (Honwana and Isaacman 1988; Penvenne 1989; Moreira 1997; Lopes 1998; Rocha 2006; infopedia http://www.infopedia.pt/\$o-brado-africano, accessed July 2010). These developments evoke a similarly divided attitude among the South African mission-educated black elite of the same period, represented by the likes of Jabavu, Plaatje, Dube, etc. (see Ndletyana 2008), who, if with misgivings, expressed themselves both in English and in their own languages.

These facts underline the literary tradition local languages, mostly Ronga, can boast, which contradict categorical statements such as the absence of "any prior tradition of bilingual education" in Mozambique (p1). Such silence is regrettable. Limited as it may have been, with to-day's situation in mind, this remarkable episode, constantly underplayed in official history - Albasini's pieces in Portuguese and Ronga are yet to be compiled and studied - may be pregnant of a promising future ${ }^{\mathrm{a}}$. Then was a time when the main non-white intellectuals published in a truly bilingual fashion, not shrinking from writing in their own as well as in the colonial language. This reminds us of the responsibility of intelligentsias in matters cultural and linguistic. The school may well start rehabilitating African languages, but, for their written use to outgrow school manuals, it has to be adopted and become common practices. If the opportunity presently opened in Mozambique for linguistic transformation is not to be wasted, what the early assimilados did in terms of vernacular writing must be emulated by Mozambican intellectuals of the day. In that respect, the recent celebration of Bento Sitoe's achievements as an academic and an inspired Ronga novelist and play-writer is encouraging, and it is reassuring to see, after a timid start, that shelves in Maputo's bookshops unashemedly display new helpings of books in local languages.

\section{Endnotes}

${ }^{a}$ After the completion of this piece I was made aware of the existence of the Cooperative Africana Microform Project (CAMP) which « micro-filmed nearly complete run of » both O Africano and O Brado Africano (see Penvenne 2010).

Competing interest

The authors declare that they have no competing interests.

Acknowledgements

I am very grateful to Andy Kirkpatrick for his professional dedication, both in terms of his insightful comments on a previous version, and his administrative follow up which saw the paper through.

Author details

${ }^{1}$ Research Fellow, Center for Research on the Politics of Language, University of Pretoria, Pretoria, South Africa. ${ }^{2}$ IFAS, Johannesburg, South Africa. ${ }^{3}$ LLACAN-CNRS UMR 8135, Paris, France.

Received: 4 February 2013 Accepted: 5 February 2013

Published: 25 February 2013

References

Alidou, H. 2004. Medium of Instruction in Post-Colonial Africa. In Medium of Instruction policies: which agenda? whose agenda? ed. JW Tollefson and AB Tsui, 195-213. Mahwah: NJ \& Erlhaum, L.

Benrabah, M. 2007. The Language planning and policy in Algeria. In Language planning and policy: Africa, ed. RB Baldauf and RB Kaplan. Clevedon; Buffalo: Multilingual Matters. vol 2, Algeria, Côte d'Ivoire, Nigeria and Tunisia 25148. http://www.columbia.edu/cgi-bin/cul/resolve?clio8758310.

Chimbutane, F, and C Benson. 2012. Expanded spaces for mozambican languages in primary education: where bottom-up meets top-down. International Multilingual Research Journal 6(1): 8-21.

Cruz e Silva, T. 2001. Igrejas Protestantes e Consciência Política no Sul de Moçambique: O caso da Missão Suiça (19301974), 286. Maputo: Promedia. 
Firmino, G. 2005. A "Questão Linguística" na Africa pós-colonial. O caso do Português e das línguas Autóctones em Moçambique Maputo: Texto Editores.

Geffray, C. 1990. La cause des armes au Mozambique: anthropologie d'une guerre civile Paris. Nairobi: Karthala CREDU. Governo de Moçambique. 2004. Constitução Maputo Imprensa nacional 97. http://www.portaldogoverno.gov.mz/ Legisla/constituicao_republica/, visited December 2012.

Governo de Moçambique. 2006. Plano Estratégico de Educação e Cultura 2006-200/2011 - Fazer da escola um polo de desenvolvimento consolidando Moçambicanidade Ministerio da Educação e Cultura (MEC) Maputo, 147. Imprensa nacional.

Harries, P. 2007. Butterflies \& barbarians: Swiss missionaries \& systems of knowledge in South-East Africa Oxford. xvii, 286. Harare, Johannesburg, Athens: James Currey; Weaver Press; Wits University Press; Ohio University Press.

Honwana, RBM, and AF Isaacman. 1988. The life history of Raúl Honwana: an inside view of Mozambique from colonialism to independence, 1905-1975. ix, 181. Boulder: L. Rienner Publishers.

Kamwangamalu, NM. 2008. Language Policy, Vernacular, Education and Language Economics in Postcolonial Africa. In Language as Commodity - Global Structures, Local Marketplaces, ed. PKW Tan and R Rubdy, 171-186. London; New York: Continuum International Publishing Group.

Lafon, M. 2008. Mozambique, vers la reconnaissance de la réalité plurilingue par l'introduction de l'éducation bilingue. In Langues, Cultures et Développement, ed. H Tourneux, 217-250. Paris: Karthala. http://halshs.archives-ouvertes.fr/ halshs-00315939/fr/

Lafon, M. 2011. L'Envers du Décor. Les Politiques Coloniales relatives à l'usages des Langues africaines à l'école continuent de commander les attitudes. Contrastes entre Afrique du Sud et Mozambique. In Plurilinguisme, politique linguistique et éducation. Quels éclairages pour Mayotte? ed. F Laroussi and F Liénard, 431-448. Rouen: Presses Universitaires Rouen Le Havre.

Lafon, M. 2012. Educação Bilingue em Moçambique: Interesse Popular Ultrapassa a Timidez Inicial do Programa. In Educação Bilingue em Moçambique: Reflectindo Criticamente sobre Políticas e Práticas, ed. F Chimbutane and C Stroud. Texto Editores: Maputo.

Lafon, M. 2013 (forthcoming). L'Introduction des Lanques Africaines dans le Système Educatif au Mozambique signale-t -elle le Dépassement de l'Assimilation? Bloemfontein: Proceedings of the IALL conference. 2010.

Lopes, AJ. 1998. Universities and research: papers from Maputo: II UEM Research Seminar, Eduardo Mondlane University Maputo, Mozambique, 28-30. IV.1998. Maputo: Livraria Universitaria.

Matusse, R. 1994. The future of Portuguese in Mozambique, African Linguistics at the Crossroads. Swaziland: Kwaluseni.

Mondlane, E. 1979. Mozambique, de la colonisation portugaise à la libération nationale P. Centre d'Information sur le Mozambique trad, 258. Paris: L'Harmattan.

Moreira, J. 1997. Os Assimilados, João Albasini e as Eleições 1900-1922 Maputo, 224. Arquivo Historico de Moçambique.

Mugomba, AT. 1981. Revolutionary Development and Educational Decolonization in Mozambique. In Independence without Freedom - The Political Economy of Colonial Education in Southern Africa, ed. AT Mugomba and M Nyaggah, 214-225. Santa Barbara: ABC-Clio.

Ndletyana, M. 2008. African Intellectuals in 19th and early 20th century. South Africa Cape Town: HSRC.

Penvenne, J. 1989. In The Creation of Tribalism in Southern Africa, ed. L Vail, 256-281.

Penvenne, J. 2010. Review of Valdemir Zamparoni. De escravo a cozinheiro: Colonialismo \& racismo em Moçambique Salvador: Editora da Universidade Federal da Bahia, 2007, 2H-Luso-Africa. http://www.h-net.org/reviews/showpdf. php?id=25076 visited February 2013.

Qorro, MAS. 2009. Parents' and Policy Makers' Insistence on Foreign Languages as Media of Instruction in Africa: restricting access to quality education - for whose benefit? In Languages and Education in Africa, a comparative and transdiciplinary analysis, ed. B Brock-Utne and I Skattum, 57-82. Bristol Papers in Education comparative and international studies Symposium Book.

Rocha, A. 2006. Associativismo e Nativismo em Moçambique - Contribuição para o estudo das Origens do Nacionalismo Moçambicano, 287. Maputo: Texto Editores.

Rothwell, P. 2001. The phylomorphic linguistic tradition: or, the siege of the Portuguese in Mozambique. Hispanic Research Journal 2(2): 165-176.

Stroud, C. 2007. Bilingualism: Colonialism and postcolonialism. In Bilingualism: A Social Approach, ed. M Heller, 25-49. Londres: Palgrave.

Tsui, AB, and JW Tollefson. 2004. The Centrality of Medium-of-Instruction Policy in Sociopolitical Processes. In Medium of Instruction policies: which agenda? whose agenda? ed. JW Tollefson and AB Tsui, 1-20. Mahwah: Erlbaum.

doi:10.1186/2191-5059-3-2

Cite this article as: Lafon: Chimbutane, Feliciano 2011. Rethinking bilingual education in postcolonial contexts. N. H. Hornberger and C. Baker ed Bristol, Buffalo, Toronto: multilingual matters. 183p.. Multilingual Education 2013 3:2. 